\title{
Management Issues in Conjunctival Tumours: Conjunctival Melanoma and Primary Acquired Melanosis
}

\author{
Victoria M. L. Cohen (D) - Roderick F. O’Day
}

Received: September 16, 2019 / Published online: November 6, 2019

(C) The Author(s) 2019

\begin{abstract}
Conjunctival melanoma is a rare malignant condition of the ocular surface. It is potentially lethal, with regional lymph node spread often preceding distant solid-organ metastasis. Due to its rarity and the long latency between treatment and local recurrence or the development of metastases, it is difficult to study. The literature is composed entirely of case series of varying quality, and there is significant variability in the management of this condition. This commentary attempts to distil the evidence base to provide practical management tips for the clinician.
\end{abstract}

Keywords: Adjuvant chemotherapy; Adjuvant radiotherapy; Conjunctival melanoma;

Enhanced digital features To view enhanced digital features for this article go to https://doi.org/10.6084/ m9.figshare.9971156.

V. M. L. Cohen $(\bowtie) \cdot$ R. F. O'Day

Ocular Oncology Service, Moorfields Eye Hospital and St Bartholomew's Hospital, London, UK

e-mail: victoria.cohen@nhs.net

V. M. L. Cohen

NIHR Biomedical Research Centre for

Ophthalmology at Moorfields Eye Hospital,

University College London Institute of

Ophthalmology, London, UK
Immunotherapy; Ocular oncology; Primary acquired melanosis

\section{Key Summary Points}

Why carry out this study?

The management of primary acquired melanosis (PAM) and conjunctival melanoma is controversial and widely variable, in large part due to the limitations of the evidence base.

This review aims to critically appraise the literature and provide a guide to the clinical management of PAM and conjunctival melanoma.

What was learned from this study?

Our clinical approach to PAM and conjunctival melanoma is outlined, and our interpretation of the literature is explained.

\section{INTRODUCTION}

Conjunctival melanoma, which is potentially life-threatening, accounts for $12 \%$ of referrals to an ocular oncology service [1]. Its incidence 
appears to be increasing. A sevenfold increase in its incidence was found in Sweden between 1960 and 2005, to approximately 0.6 cases/ million/year [2]. A similar change was found in Finland with an increase from 0.4 to 0.8 cases/ million/year, as well as in the USA $[3,4]$. This may be due to increased ultraviolet light exposure and corresponds with a comparable increase in the incidence of cutaneous melanoma [4]. It is more common in Caucasians, the elderly and men [2, 3, 5]. Its most frequent clinical presentation is as an enlarging, pigmented nodular or thickened bulbar conjunctival lesion [6]. It can, however, affect any location of the cornea, bulbar or tarsal conjunctive and lid margin. Non-typical tumours, such as amelanotic lesions, can pose a significant diagnostic dilemma and be diagnosed late [7]. Conjunctival melanoma can arise de novo, from primary acquired melanosis (PAM) or from a conjunctival naevus $[5,6,8]$.

The diagnosis and management of PAM and conjunctival melanoma are controversial; its rarity and long follow-up required make clinical trials difficult, and there is significant variation between centres. For example at least three different terms have been proposed to describe acquired conjunctival pigmentation with dysplastic melanocytes. Of these, 'PAM' is the earliest described and most widely adopted term, and is used at our institution $[9,10]$. However, Ackerman argued that PAM should be called 'melanoma in situ', similar to lentigo maligna of the skin [11]. Damato and Coupland proposed the term 'conjunctival melanocytic intraepithelial neoplasia', or C-MIN, with a 10-point pathological grading based on three factors: melanocyte proliferation, depth of invasion and degree of cellular atypia [12]. In addition, the evidence base for the management of PAM and conjunctival melanoma offers little more clarity. The literature is confined to case series. There are no comparator studies. Moreover, the natural history of PAM and conjunctival melanoma is that the disease often recurs and metastasises late. Many of the published case series do not have adequate follow-up to reflect this. This commentary aims to critically appraise the literature and provide a guide to the clinical management of PAM and conjunctival melanoma. This article is based on previously conducted studies and does not contain any studies with human participants or animals performed by any of the authors.

\section{MANAGEMENT ISSUES IN CONJUNCTIVAL MELANOMA}

\section{What is the Optimal Treatment of PAM?}

PAM appears clinically as a unilateral, acquired area of conjunctival pigmentation. It occurs most commonly in Caucasians in the sixth decade of life [13]. Up to $75 \%$ of all conjunctival melanomas arise from PAM, but they have better prognosis than those arising de novo [6]. The extent of the conjunctiva involved by PAM is the most important clinical risk factor for development of conjunctival melanoma; For example PAM that involves 4 and 12 clock hours of conjunctiva is 7 and 20 times more likely, respectively, to develop melanoma than lesions involving 1 clock hour [13]. Full-thickness biopsy, incisional or excisional, is required to rule out invasive melanoma and assess degree of atypia [14]. Cases of PAM with no or mild atypia almost never transform into melanoma, whereas $13-46 \%$ of cases with severe atypia do so $[13,15,16]$.

There is considerable heterogeneity in the management of PAM. Some groups treat PAM aggressively. A described treatment algorithm depends on the degree of conjunctiva involved. If less than 2 clock hours of conjunctiva is involved, close clinical monitoring is felt to be appropriate. For PAM lesions of 2-5 clock hours of conjunctiva, excisional biopsy and cryotherapy to conjunctival edges are advocated. For lesions greater than 5 clock hours, wide incisional biopsy and cryotherapy to all remaining conjunctival pigmentation are performed $[10,13,17,18]$. At the other end of the spectrum, some groups advocate clinical monitoring for all patients with areas of acquired flat conjunctival pigmentation, and biopsy only if there are clinical features consistent with melanoma such as conjunctival thickness, intrinsic vascularity, feeder vessels and progression, or multiple risk factors for melanoma development such 
as intense dark appearance, corneal involvement and palpebral location [19]. We subscribe to this more conservative approach, especially as the pigmentation of PAM may spontaneously 'wax and wane', appearing more pigmented as daylight hours increase. In addition, multiple surgery and cryotherapy procedures can lead to excess conjunctival and corneal scarring, resulting in discomfort, restricted eye movement and reduced vision.

The treatment options for PAM are surgical excision, cryotherapy and topical mitomycin C (MMC) [10]. However, no trials have demonstrated that treatment prevents recurrence of PAM or its progression to conjunctival melanoma. Practice patterns are largely formed based on clinical experience. Recurrence rates of PAM with atypia after primary treatment with topical MMC are up to $38 \%$ (three of eight patients), as was found in a case series with mean follow-up of 81 months [20]. Care must be taken in interpreting the results of other case series with shorter follow-up, such as that of Fruch-Pery et al. [21] which found PAM recurrence in only 1 of 12 patients treated with topical MMC but with a mean follow-up of 24 months, as recurrences of PAM can take many years to occur [22]. Similarly, recurrence rates of PAM with severe atypia after surgery and cryotherapy are 50\% in eyes with at least 3 years of follow-up [13]. In the Shields series, which is the largest to date, employing their treatment strategy outlined above, no difference was found in the rates of PAM lesions progressing to conjunctival melanoma at 5 and 10 years when comparing eyes that were initially observed with those that were initially managed surgically [13]. It is true that the lesions that were initially observed were smaller than those that were initially biopsied in that series, and therefore should have had a lower rate of developing conjunctival melanoma [13]. However, extensive surgery and topical chemotherapy are not without risks.

Our approach to suspected PAM is as follows:

1. Full-thickness biopsy in all patients at baseline:
- If a small conjunctival area is involved and surgical morbidity is likely low: excisional biopsy

- If a large conjunctival area is involved: mapping biopsies

2. Further management depends on the degree of atypia found:

- No atypia: discharge for local follow-up

- Atypia of any grade: follow up at an ocular oncology service every 6 months lifelong with clinical examination and slit-lamp photography:

- If an area subsequently becomes suspicious for conjunctival melanoma, excisional biopsy and cryotherapy to conjunctival edges (see below)

- Invasive melanoma: treatment as for melanoma (see below)

\section{What is the Optimal Management of Circumscribed Conjunctival Melanoma?}

Conjunctival melanoma is potentially lethal. Metastasis is most commonly begin in the regional lymph nodes, i.e. the submandibular and preauricular lymph nodes, but approximately $25 \%$ of patients will develop distant metastases with no concurrent regional lymph node disease [23]. Unlike uveal melanoma, where, in $90 \%$ of cases, distant solid-organ metastatic disease begins in the liver, conjunctival melanoma shows no strong predilection for any particular organ [24]. It spreads more commonly to the lungs, liver and brain, but also to the peritoneum and skin, amongst other sites $[8,23,25,26]$. Therefore, it is important to undertake staging and surveillance for conjunctival melanoma. This is discussed in the section on sentinel node biopsy.

Conjunctival melanomas arising de novo have higher metastatic rates than those arising from naevi or PAM [6]. Other risk factors for spread include non-bulbar conjunctival location (in particular medial and caruncular), thickness greater than $2 \mathrm{~mm}$, ulceration on the tumour surface and local recurrence 
$[8,13,23,27-30]$. Recent studies also suggest that tumour genetics are important in the development of metastatic disease. Larsen et al., in a retrospective review of 139 patients from Denmark, found that tumours with $B R A F$ mutations were eight times more likely to metastasise than those without (32\% versus $4 \%$ ) [26]. Conjunctival melanoma has 5- and 10-year tumour-related mortality of $12-19 \%$ and $23-39 \%$, respectively $[2,5,8,23,29,31,32]$.

In 1997, Shields et al. described a surgical technique that has been widely adopted for resection of circumscribed conjunctival melanoma [33, 34]. It consists of wide local excision using a 'no-touch technique'. Corneal disease is removed after alcohol epitheliectomy. The target conjunctival margin is $5 \mathrm{~mm}$ from the tumour edge, and partial-thickness lamellar sclerectomy is performed starting $2-3 \mathrm{~mm}$ from the tumour. Cryotherapy is applied to the conjunctival margins, and reconstruction is performed with new instruments [33, 34]. Local tumour recurrence occurs in $18-35 \%$ of patients after using these techniques [5, 32]. Over the past 15 years, there has been a shift to performing less-invasive surgery to reduce ocular morbidity. This includes smaller conjunctival margins and avoiding lamellar sclerectomy unless the tumour is firmly adherent to the sclera. Cryotherapy to the conjunctival margins, however, remains crucial in the surgical treatment of conjunctival melanoma. It significantly reduces rates of local recurrence and should be used in all patients with suspected conjunctival melanoma $[26,35]$. The reason for this shift in surgical technique is the lowered recurrence rates that have occurred with increased uptake of adjuvant therapies, particularly adjuvant radiotherapy [30, 36]. Incisional biopsies are associated with higher rates of recurrence, metastasis and death [25]. They are not recommended in patients with suspected conjunctival melanoma.

Radiotherapy for conjunctival tumours was first described by Treacher-Collins in 1917 [37]. It is now commonly used as adjuvant therapy after excisional biopsy and cryotherapy for patients with invasive conjunctival melanoma throughout Europe and in Australia $[29,30,35,36,38-43]$. It has not been as widely adopted in North America, except for advanced disease with poor prognosis [10, 44]. Radiotherapy can be delivered by using a strontium applicator [38], ruthenium [30] or iodine plaque $[36,41,43]$, or as external-beam radiotherapy [42]. There are no randomised controlled trials of adjuvant radiotherapy following surgical excision of conjunctival melanoma. However, a retrospective audit of 76 patients treated in Liverpool found a significant decrease in rates of local recurrence after introducing routine ruthenium plaque brachytherapy following surgical excision and cryotherapy of all conjunctival melanomas, including those completely excised on histopathological review of surgical margins. Their 5-year local recurrence rate fell from $24 \%$ to $5 \%$ [30]. In a retrospective case series of 19 patients, Karim and Conway applied iodine plaque brachytherapy for early conjunctival melanoma showing invasion of the substantia propria of up to $1.5 \mathrm{~mm}$, after limited surgical resection and cryotherapy. They found no local recurrence at mean followup of 43 months, although there were new melanomas at different sites in three patients [36]. At our institution, we use a strontium applicator which delivers beta radiation. The advantages of the strontium applicator are that it does not require a surgical procedure or general anaesthetic to insert or remove a plaque and that it can be easily performed in a radiation-controlled, outpatient setting under topical anaesthesia. We apply a total dose of $50 \mathrm{~Gy}$ fractionated over 5 days. The indication for its use in our department is incomplete excision at the deep surgical margin on histopathological review [38]. Using the less-invasive surgical technique routinely performed in our department, disease-free deep surgical margins of bulbar conjunctival melanomas are rare, and almost all patients proceed to strontium radiotherapy. Using this indication, we have reported a recurrence rate of $10 \%$ with median follow-up of 59 months. This higher rate of recurrence as compared with Damato et al. may be due to selection bias, as all patients who received strontium radiotherapy in our department had incomplete excision at the deep margin and therefore a higher risk of local recurrence. Side effects following strontium-90 
beta radiotherapy were limited to mild dry-eye symptoms; no patient developed a radiationinduced cataract, scleral melt or anterior segment neovascularisation [38], indicating significantly less side effects compared with other radioactive sources [30, 36].

The role of topical chemotherapy for conjunctival melanoma is controversial and evolving $[22,45]$. It has the advantage of being able to treat the entire conjunctival surface and is, therefore, theoretically suited to patients with extensive or multifocal PAM or recurrent conjunctival melanoma. Evidence for the use of topical interferon- $\alpha 2 b$ (IFN- $\alpha 2 b)$ and 5-fluorouracil, which are commonly applied in the management of ocular surface squamous neoplasia, is limited. Topical IFN- $\alpha 2 b$ has been used as an adjuvant after surgical resection and cryotherapy with or without positive histopathological margins, if patients have been intolerant to, or failed, topical MMC [46-48]. However, the case series are small and the indications for its use vary. Caution should be exercised in interpreting them.

The most widely investigated topical chemotherapy for patients with conjunctival melanoma is MMC $0.04 \%$. It has been used in non-comparative case series as primary or adjuvant therapy for conjunctival melanoma, particularly in the setting of coexistent PAM with atypia [8, 20,49-51]. The largest series was reported by Ditta et al. [49], including 15 patients with conjunctival melanoma arising from PAM who received three cycles of MMC $0.04 \%$ QID for 1 week on and 1 week off after wide local excision with cryotherapy [49]. Five of $15(33 \%)$ had local recurrence with median follow-up of 24 months, and the 5-year estimated recurrence rate was 39\% [49]. Common complications after MMC are keratopathy, ocular irritation and limbal stem cell deficiency, although reported rates of long-term complications vary from zero, to up to $80 \%[49,52]$. MMC $0.04 \%$ does not readily penetrate the basement membrane, and subepithelial disease, in particular nodular recurrences, is resistant $[50,51]$. A common issue in interpreting recurrence rates reported in series of conjunctival melanoma arising from PAM is whether the recurrence is a new lesion at a new location of coexistent PAM or recurrent disease at the same location. It will be important for future studies to clearly delineate these so that the role for adjuvant topical chemotherapy can be better defined.

Our preference for lateral conjunctival margin control is surgical excision with cryotherapy. We use topical MMC $0.04 \%$ as adjuvant therapy if a patient has coexistent, extensive or multifocal PAM with atypia after excision and cryotherapy of a conjunctival melanoma, or in recurrent disease.

Our approach to circumscribed conjunctival melanoma is as follows:

1. Complete surgical resection and adjuvant double free-thaw cryotherapy using 'notouch' technique:

- Lateral conjunctival margins of $2 \mathrm{~mm}$ or more

- Resection down to bare sclera, partialthickness lamellar sclerectomy only if lesion is firmly adherent to sclera

- Cryotherapy to conjunctival margins and limbal sclera if adherent disease

2. Adjuvant treatment:

- Strontium applicator if surgical deep margins involved

- Adjuvant mitomycin C $0.04 \%$ if conjunctival melanoma found in a patient with extensive or multifocal PAM with atypia, or in recurrent cases

\section{What is the Role of Sentinel Lymph Node Biopsy?}

Sentinel lymph node (SLN) biopsy is advocated as a means to detect micro-metastases in regional lymph nodes prior to being identifiable by clinical examination or imaging techniques, such as ultrasound, magnetic resonance imaging (MRI) or positron emission tomography (PET)-computed tomography (CT). The goal is to prevent more distant spread, as well as provide prognostic information [53]. Lymphoscintigraphy is used to identify the sentinel lymph nodes, which are then surgically removed by a head and neck or ear, nose, throat 
surgeon. If SLN is positive, radical lymph node dissection is recommended, as well as consideration of local radiotherapy or systemic chemotherapy [53]. Patients who are at high risk for regional spread are selected for SLN biopsy. The main indications are histological tumour thickness $\geq 2 \mathrm{~mm}$, histological tumour ulceration, non-limbal location and multiply recurrent disease in patients with extensive PAM [54, 55]. In these patients, $11-17 \%$ will have positive SLN biopsy [54-56].

The major risk of SLN biopsy is facial nerve palsy if dissection is required in parotid region. In our prospective case series of 22 patients, only 1 had transient facial nerve palsy [55]. The risk can by reduced if the anaesthetist does not administer a muscle relaxant so that facial twitch, a sign of irritation of the facial nerve, can be noticed by the surgeon [55]. SLN biopsy should be performed by experienced surgeons with a low threshold to abandon the surgery if faced with complex anatomy or deep parotid dissection. False-negative rates have fallen with experience, and in our prospective case series there were none, although in 4 of $22(18 \%)$ patients the SLN could not be located using the technetium-99 probe [55]. The number of patients treated with SLN biopsy for conjunctival melanoma is too small to derive information regarding its impact on distant metastasis or survival. However, SLN biopsy is validated by the improved disease-free survival for patients with cutaneous melanoma found in the Multicenter Selective Lymphadenectomy Trial-1, providing proof of concept for its potential role in the management of conjunctival melanoma [57].

\section{What is the Role of Immunotherapy?}

Conjunctival melanoma has many genetic features in common with cutaneous melanoma, as opposed to uveal melanoma $[58,59]$. In particular, $23-50 \%$ will have $B R A F$ mutations [26, 60-62]. Conjunctival melanomas with $B R A F$ mutations appear to be more likely to metastasise [26]. In cutaneous melanoma, activation of the mitogen-activated protein kinase (MAPK) pathway via somatic mutations in $B R A F$ is present in $40-60 \%$ of cases [63]. BRAF mutations have been associated with worse prognosis in cutaneous melanoma, but immunotherapy with BRAF and MEK inhibitors has improved survival in non-resectable metastatic disease [64]. Similarly, these show great promise in conjunctival melanoma, although experience with this treatment to date is limited [65-67]. Other immunotherapy agents which have begun to be used for non-resectable local and metastatic disease are checkpoint inhibitors, such as the anti-programmed cell death inhibitors (PD1 inhibitors) nivolumab and pembrolizumab [68, 69]. When considering a PD1 inhibitor for non-resectable conjunctival melanoma to avoid orbital exenteration, possible systemic side effects including multi-organ failure should be fully discussed with the patient. Shared care with a medical oncologist is essential. Given the significant improvement in the treatment of metastatic cutaneous melanoma with immunotherapeutic agents and the genetic similarities between conjunctival and cutaneous melanoma, there is great hope that immunotherapy will have similar results in conjunctival melanoma.

\section{CONCLUSIONS}

This commentary highlights our approach to the clinical management of patients with conjunctival melanoma, with a critical appraisal of the evidence base. Much controversy and difference in practice patterns exist in this field. Treatment strategies should be adapted to the individual patient's needs. Future multi-centre comparative clinical trials would be of significant benefit in answering the management issues discussed in this commentary.

\section{ACKNOWLEDGEMENTS}

Funding. No funding or sponsorship was received for publications of this article.

Authorship. All named authors meet the International Committee of Medical Journal 
Editors (ICMJE) criteria for authorship for this article, take responsibility for the integrity of the work as a whole, and have given their approval for this version to be published.

Disclosures. Victoria Cohen and Roderick O'Day declare that they have no conflict of interest.

Compliance with Ethics Guidelines. This article is based on previously conducted studies and does not contain any studies with human participants or animals performed by any of the authors.

Open Access. This article is distributed under the terms of the Creative Commons Attribution-NonCommercial 4.0 International License (http://creativecommons.org/licenses/ by-nc/4.0/), which permits any noncommercial use, distribution, and reproduction in any medium, provided you give appropriate credit to the original author(s) and the source, provide a link to the Creative Commons license, and indicate if changes were made.

\section{REFERENCES}

1. Shields CL, Alset AE, Boal NS, et al. Conjunctival tumors in 5002 cases. Comparative analysis of benign versus malignant counterparts. The 2016 James D. Allen lecture. Am J Ophthalmol. 2017;173:106-33. https://doi.org/10.1016/j.ajo. 2016.09.034.

2. Triay E, Bergman L, Nilsson B, All-Ericsson C, Seregard S. Time trends in the incidence of conjunctival melanoma in Sweden. Br J Ophthalmol. 2009;93(11):1524-8. https://doi.org/10.1136/bjo. 2009.157933.

3. Tuomaala S, Eskelin S, Tarkkanen A, Kivelä T. Population-based assessment of clinical characteristics predicting outcome of conjunctival melanoma in whites. Invest Ophthalmol Vis Sci. 2002;43(11):3399-408.

4. $\mathrm{Yu}$ G-P, Hu D-N, McCormick S, Finger PT. Conjunctival melanoma: is it increasing in the United States? Am J Ophthalmol. 2003;135(6):800-6.

5. De Potter P, Shields CL, Shields JA, Menduke H. Clinical predictive factors for development of recurrence and metastasis in conjunctival melanoma: a review of 68 cases. Br J Ophthalmol. 1993;77(10):624-30. https://doi.org/10.1136/bjo. 77.10 .624 .

6. Shields CL, Markowitz JS, Belinsky I, et al. Conjunctival melanoma: outcomes based on tumor origin in 382 consecutive cases. Ophthalmology. 2011;118(2):389-95. https://doi.org/10.1016/j. ophtha.2010.06.021 (e1-2).

7. Paridaens AD, McCartney AC, Hungerford JL. Multifocal amelanotic conjunctival melanoma and acquired melanosis sine pigmento. Br J Ophthalmol. 1992;76(3):163-5. https://doi.org/10.1136/ bjo.76.3.163.

8. Werschnik C, Lommatzsch PK. Long-term followup of patients with conjunctival melanoma. Am J Clin Oncol. 2002;25(3):248-55.

9. Folberg R, McLean IW, Zimmerman LE. Primary acquired melanosis of the conjunctiva. Hum Pathol. 1985;16(2):129-35. https://doi.org/10. 1016/s0046-8177(85)80061-7.

10. Shields CL, Shields JA. Tumors of the conjunctiva and cornea. Surv Ophthalmol. 2004;49(1):3-24.

11. Ackerman AB, Sood R, Koenig M. Primary acquired melanosis of the conjunctiva is melanoma in situ. Mod Pathol. 1991;4(2):253-63.

12. Damato B, Coupland SE. Conjunctival melanoma and melanosis: a reappraisal of terminology, classification and staging. Clin Experiment Ophthalmol. 2008;36(8):786-95. https://doi.org/10.1111/j. 1442-9071.2008.01888.x.

13. Shields JA, Shields CL, Mashayekhi A, et al. Primary acquired melanosis of the conjunctiva: risks for progression to melanoma in 311 eyes. The 2006 Lorenz E. Zimmerman lecture. Ophthalmology. 2008;115(3):511.e2-519.e2. https://doi.org/10. 1016/j.ophtha.2007.07.003.

14. Jakobiec FA, Folberg R, Iwamoto T. Clinicopathologic characteristics of premalignant and malignant melanocytic lesions of the conjunctiva. Ophthalmology. 1989;96(2):147-66. https://doi.org/10. 1016/s0161-6420(89)32920-4.

15. Seregard S. Conjunctival melanoma. Surv Ophthalmol. 1998;42(4):321-50.

16. Folberg R, McLean IW. Primary acquired melanosis and melanoma of the conjunctiva: terminology, classification, and biologic behavior. Hum Pathol. 1986;17(7):652-4. https://doi.org/10.1016/s0046$8177(86) 80175-7$. 
17. Oellers P, Karp CL. Management of pigmented conjunctival lesions. Ocul Surf. 2012;10(4):251-63. https://doi.org/10.1016/j.jtos.2012.08.002.

18. Jakobiec FA, Rini FJ, Fraunfelder FT, Brownstein S. Cryotherapy for conjunctival primary acquired melanosis and malignant melanoma. Experience with 62 cases. Ophthalmology. 1988;95(8):1058-70. https://doi.org/10.1016/ s0161-6420(88)33058-7.

19. Gloor P, Alexandrakis G. Clinical characterization of primary acquired melanosis. Gaz Med Fr. 1995;36(8):1721-9.

20. Kurli M, Finger PT. Topical mitomycin chemotherapy for conjunctival malignant melanoma and primary acquired melanosis with atypia: 12 years' experience. Graefes Arch Clin Exp Ophthalmol Albrecht Von Graefes Arch Klin Exp Ophthalmol. 2005;243(11):1108-14. https://doi.org/10.1007/ s00417-004-1080-y.

21. Pe'er J, Frucht-Pery J. The treatment of primary acquired melanosis (PAM) with atypia by topical mitomycin C. Am J Ophthalmol. 2005;139(2):229-34. https://doi.org/10.1016/j.ajo. 2004.08.065.

22. Chalasani R, Giblin M, Conway RM. Role of topical chemotherapy for primary acquired melanosis and malignant melanoma of the conjunctiva and cornea: review of the evidence and recommendations for treatment. Clin Experiment Ophthalmol. 2006;34(7):708-14. https://doi.org/10.1111/j.14429071.2006.01356.x.

23. Esmaeli B, Wang X, Youssef A, Gershenwald JE. Patterns of regional and distant metastasis in patients with conjunctival melanoma: experience at a cancer center over four decades. Ophthalmology. 2001;108(11):2101-5.

24. Diener-West M, Reynolds SM, Agugliaro DJ, et al. Development of metastatic disease after enrollment in the COMS trials for treatment of choroidal melanoma: Collaborative Ocular Melanoma Study Group Report No. 26. Arch Ophthalmol Chic Ill 1960. 2005;123(12):1639-43. https://doi.org/10. 1001/archopht.123.12.1639.

25. Larsen A-C, Dahmcke CM, Dahl C, et al. A retrospective review of conjunctival melanoma presentation, treatment, and outcome and an investigation of features associated with BRAF mutations. JAMA Ophthalmol. 2015;133(11):1295-303. https://doi.org/10.1001/ jamaophthalmol.2015.3200.

26. Larsen A-C, Dahl C, Dahmcke CM, et al. BRAF mutations in conjunctival melanoma: investigation of incidence, clinicopathological features, prognosis and paired premalignant lesions. Acta Ophthalmol (Copenh). 2016;94(5):463-70. https:// doi.org/10.1111/aos.13007.

27. Missotten GS, de Wolff-Rouendaal D, de Keizer RJW. Screening for conjunctival melanoma metastasis: literature review. Bull Soc Belge Ophtalmol. 2007;306:23-30.

28. Jakobiec FA. Conjunctival melanoma. Arch Ophthalmol Chic Ill 1960. 1981;99(3):513-6. https:// doi.org/10.1001/archopht.1981.03930010514031.

29. Lommatzsch PK, Lommatzsch RE, Kirsch I, Fuhrmann P. Therapeutic outcome of patients suffering from malignant melanomas of the conjunctiva. Br J Ophthalmol. 1990;74(10):615-9. https://doi.org/ 10.1136/bjo.74.10.615.

30. Damato B, Coupland SE. An audit of conjunctival melanoma treatment in Liverpool. Eye Lond Engl. 2009;23(4):801-9. https://doi.org/10.1038/eye. 2008.154 .

31. Paridaens AD, Minassian DC, McCartney AC, Hungerford JL. Prognostic factors in primary malignant melanoma of the conjunctiva: a clinicopathological study of 256 cases. Br J Ophthalmol. 1994;78(4):252-9. https://doi.org/10.1136/bjo.78. 4.252 .

32. Shields CL. Conjunctival melanoma: risk factors for recurrence, exenteration, metastasis, and death in 150 consecutive patients. Trans Am Ophthalmol Soc. 2000;98:471-92.

33. Shields JA, Shields CL, De Potter P. Surgical management of circumscribed conjunctival melanomas. Ophthal Plast Reconstr Surg. 1998;14(3):208-15.

34. Shields JA, Shields CL, De Potter P. Surgical management of conjunctival tumors. The 1994 Lynn B. McMahan Lecture. Arch Ophthalmol Chic Ill 1960. 1997;115(6):808-15.

35. Brouwer NJ, Marinkovic M, van Duinen SG, Bleeker JC, Jager MJ, Luyten GPM. Treatment of conjunctival melanoma in a Dutch referral centre. $\mathrm{Br} \mathrm{J}$ Ophthalmol. 2018;102(9):1277-82. https://doi.org/ 10.1136/bjophthalmol-2017-311082.

36. Karim R, Conway RM. Conservative resection and adjuvant plaque brachytherapy for early-stage conjunctival melanoma. Clin Experiment Ophthalmol. 2011;39(4):293-8. https://doi.org/10. 1111/j.1442-9071.2010.02469.x.

37. Treacher Collins E. Case of epibulbar sarcoma cured by its removal and the application of radium. Trans Ophthal Soc UK. 1918;38:125-7. 
38. Cohen VML, Papastefanou VP, Liu S, Stoker I, Hungerford JL. The use of strontium-90 beta radiotherapy as adjuvant treatment for conjunctival melanoma. J Oncol. 2013;2013:349162. https:// doi.org/10.1155/2013/349162.

39. Lederman M, Wybar K, Busby E. Malignant epibulbar melanoma: natural history and treatment by radiotherapy. $\mathrm{Br} \mathrm{J}$ Ophthalmol. 1984;68(9):605-17. https://doi.org/10.1136/bjo.68. 9.605 .

40. Zografos L, Uffer S, Bercher L, Gailloud C. Combined surgery, cryocoagulation and radiotherapy for treatment of melanoma of the conjunctiva. Klin Monatsbl Augenheilkd. 1994;204(5):385-90. https://doi.org/10.1055/s-2008-1035564.

41. Stannard CE, Sealy GR, Hering ER, Pereira SB, Knowles R, Hill JC. Malignant melanoma of the eyelid and palpebral conjunctiva treated with iodine-125 brachytherapy. Ophthalmology. 2000;107(5):951-8. https://doi.org/10.1016/s01616420(00)00061-0.

42. Desjardins L, Poncet P, Levy C, Schlienger P, Asselain B, Validire P. Prognostic factors in malignant melanoma of the conjunctiva. An anatomo-clinical study of 56 patients. J Fr Ophtalmol. 1999;22(3):315-21.

43. Walsh-Conway N, Conway RM. Plaque brachytherapy for the management of ocular surface malignancies with corneoscleral invasion. Clin Experiment Ophthalmol. 2009;37(6):577-83. https://doi.org/10.1111/j.1442-9071.2009.02092.x.

44. Wong JR, Nanji AA, Galor A, Karp CL. Management of conjunctival malignant melanoma: a review and update. Expert Rev Ophthalmol. 2014;9(3):185-204. https://doi.org/10.1586/ 17469899.2014 .921119 .

45. Fernandes BF, Nikolitch K, Coates J, et al. Local chemotherapeutic agents for the treatment of ocular malignancies. Surv Ophthalmol. 2014;59(1):97-114. https://doi.org/10.1016/j. survophthal.2013.01.003.

46. Benage MJ, Morrow NC, Janson BJ, Greiner MA. Evaluation of interferon alpha $2 \mathrm{~b}$ as adjunctive therapy for conjunctival melanoma. Am J Ophthalmol Case Rep. 2019. https://doi.org/10.1016/j. ajoc.2019.100467.

47. Kikuchi I, Kase S, Ishijima K, Ishida S. Long-term follow-up of conjunctival melanoma treated with topical interferon alpha-2b eye drops as adjunctive therapy following surgical resection. Graefes Arch Clin Exp Ophthalmol Albrecht Von Graefes Arch Klin Exp Ophthalmol. 2017;255(11):2271-6. https://doi.org/10.1007/s00417-017-3754-2.
48. Finger PT, Sedeek RW, Chin KJ. Topical interferon alfa in the treatment of conjunctival melanoma and primary acquired melanosis complex. Am J Ophthalmol. 2008;145(1):124-9. https://doi.org/10. 1016/j.ajo.2007.08.027.

49. Ditta LC, Shildkrot Y, Wilson MW. Outcomes in 15 patients with conjunctival melanoma treated with adjuvant topical mitomycin C: complications and recurrences. Ophthalmology. 2011;118(9):1754-9. https://doi.org/10.1016/j.ophtha.2011.01.060.

50. Finger PT, Czechonska G, Liarikos S. Topical mitomycin $\mathrm{C}$ chemotherapy for conjunctival melanoma and PAM with atypia. $\mathrm{Br} \mathrm{J}$ Ophthalmol. 1998;82(5):476-9. https://doi.org/10.1136/bjo.82. 5.476 .

51. Demirci H, McCormick SA, Finger PT. Topical mitomycin chemotherapy for conjunctival malignant melanoma and primary acquired melanosis with atypia: clinical experience with histopathologic observations. Arch Ophthalmol Chic Ill 1960. 2000;118(7):885-91.

52. Khong JJ, Muecke J. Complications of mitomycin C therapy in 100 eyes with ocular surface neoplasia. Br J Ophthalmol. 2006;90(7):819-22. https://doi. org/10.1136/bjo.2005.086850.

53. Mendoza PR, Grossniklaus HE. Sentinel lymph node biopsy for eyelid and conjunctival tumors: what is the evidence? Int Ophthalmol Clin. 2015;55(1):123-36. https://doi.org/10.1097/IIO. 0000000000000051 .

54. Savar A, Ross MI, Prieto VG, Ivan D, Kim S, Esmaeli B. Sentinel lymph node biopsy for ocular adnexal melanoma: experience in 30 patients. Ophthalmology. 2009;116(11):2217-23. https://doi.org/10. 1016/j.ophtha.2009.04.012.

55. Cohen VML, Tsimpida M, Hungerford JL, Jan H, Cerio R, Moir G. Prospective study of sentinel lymph node biopsy for conjunctival melanoma. Br J Ophthalmol. 2013;97(12):1525-9. https://doi.org/ 10.1136/bjophthalmol-2013-303671.

56. Pfeiffer ML, Ozgur OK, Myers JN, et al. Sentinel lymph node biopsy for ocular adnexal melanoma. Acta Ophthalmol (Copenh). 2017;95(4):e323-8. https://doi.org/10.1111/aos.13252.

57. Morton DL, Thompson JF, Cochran AJ, et al. Final trial report of sentinel-node biopsy versus nodal observation in melanoma. $\mathrm{N}$ Engl J Med. 2014;370(7):599-609. https://doi.org/10.1056/ NEJMoa1310460.

58. Vora GK, Demirci H, Marr B, Mruthyunjaya P. Advances in the management of conjunctival 
melanoma. Surv Ophthalmol. 2017;62(1):26-42. https://doi.org/10.1016/j.survophthal.2016.06.001.

59. Spendlove HE, Damato BE, Humphreys J, Barker KT, Hiscott PS, Houlston RS. BRAF mutations are detectable in conjunctival but not uveal melanomas. Melanoma Res. 2004;14(6):449-52.

60. Gear H, Williams H, Kemp EG, Roberts F. BRAF mutations in conjunctival melanoma. Invest Ophthalmol Vis Sci. 2004;45(8):2484-8. https://doi.org/ 10.1167/iovs.04-0093.

61. Goldenberg-Cohen N, Cohen Y, Rosenbaum E, et al. T1799A BRAF mutations in conjunctival melanocytic lesions. Invest Ophthalmol Vis Sci. 2005;46(9):3027-30. https://doi.org/10.1167/iovs. 04-1449.

62. Griewank KG, Westekemper H, Murali R, et al. Conjunctival melanomas harbor BRAF and NRAS mutations and copy number changes similar to cutaneous and mucosal melanomas. Clin Cancer Res. 2013;19(12):3143-52. https://doi.org/10.1158/ 1078-0432.CCR-13-0163.

63. Long GV, Menzies AM, Nagrial AM, et al. Prognostic and clinicopathologic associations of oncogenic BRAF in metastatic melanoma. J Clin Oncol. 2011;29(10):1239-46. https://doi.org/10.1200/JCO. 2010.32 .4327$.

64. Broman KK, Dossett LA, Sun J, Eroglu Z, Zager JS. Update on BRAF and MEK inhibition for treatment of melanoma in metastatic, unresectable, and adjuvant settings. Expert Opin Drug Saf. 2019;18(5):381-92. https://doi.org/10.1080/ 14740338.2019.1607289.

65. Rossi E, Maiorano BA, Pagliara MM, et al. Dabrafenib and trametinib in BRAF mutant metastatic conjunctival melanoma. Front Oncol. 2019;9:232. https://doi.org/10.3389/fonc.2019.00232.

66. Pinto Torres S, André T, Gouveia E, Costa L, Passos MJ. Systemic treatment of metastatic conjunctival melanoma. Case Rep Oncol Med. 2017;2017:4623964. https://doi.org/10.1155/2017/ 4623964 .

67. Mor JM, Heindl LM. Systemic BRAF/MEK inhibitors as a potential treatment option in metastatic conjunctival melanoma. Ocul Oncol Pathol. 2017;3(2):133-41. https://doi.org/10.1159/ 000452473.

68. Finger PT, Pavlick AC. Checkpoint inhibition immunotherapy for advanced local and systemic conjunctival melanoma: a clinical case series. J Immunother Cancer. 2019;7(1):83. https://doi.org/10. 1186/s40425-019-0555-7.

69. Sagiv O, Thakar SD, Kandl TJ, et al. Immunotherapy with programmed cell death 1 inhibitors for 5 patients with conjunctival melanoma. JAMA Ophthalmol. 2018;136(11):1236-41. https://doi.org/10. 1001/jamaophthalmol.2018.3488. 